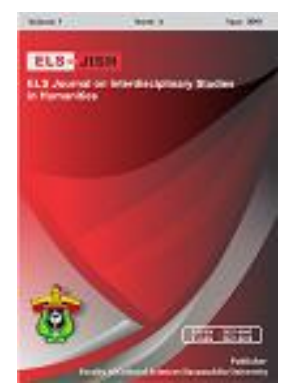

ELS-JISH

ELS Journal on Interdisciplinary Studies on Humanities

Volume 2 Issue 2, 2019

ISSN (print) : 2621-0843

ISSN (online) : 2621-0835

Homepage : http://journal.unhas.ac.id/index.php/jish

\title{
Code Switching in Pulutan Lor as The Reflection of Bilingualism
}

\author{
Nibros Hassani ${ }^{1}$, Maulida Swastuti ${ }^{2}$, Sari Famularsih ${ }^{3}$ \\ 1 nibroshassani@gmail.com
}

\begin{abstract}
In the multilingual region or community, certain social components influence language use. Moreover, in code-switching case, people sometimes switch code within a domain or social situation including the arrival of a new person and when there is some obvious change in the situation. Pulutan Lor as one of the little region in Salatiga, Central Java has got the arrival of many students since the built of new campus although they are not nameable as the permanent resident. This study aims to observe (i) How these newcomers in Pulutan Lor can give impact to society's choice in using language (ii) What is the language used in the code-switching by the people in Pulutan. The methodology used is qualitative. The findings show (i) English is dominantly used in the code-switching, secondly is Javanese, and the last is Bahasa Indonesia (ii) The newcomers in Pulutan give impact at how society uses language even in casual conversation which is reflecting bilingualism.
\end{abstract}

Keywords: Code Switching, Sociolinguistic, Bilingualism, New Comers, Pulutan Central Java

How to cite: Hassani, N., et al. (2019). Code Switching in Pulutan Lor as The Reflection of Bilingualism. ELS Journal on Interdisciplinary Studies in Humanities, 2 (2), 266-277

\section{Introduction}

As Bloomfield said, Language plays a great part in our life (Bloomfield, 1961). In the term of sociolinguistic, there are many topics could explain how social class and situational condition can give effect the way society speak or which language those preferably in certain conditions. And those are what sociolinguists mainly explore: the relationship between language and society. Moreover, Samsuri also states it in "Analisis Bahasa" that language stands as a communication tool-par excellence (Samsuri, 1991). The social factors and dimensions in sociolinguistic contribute massively in the language choice. For social factors, as Holmes mentioned (Holmes, 2013 , p. 9) the users of language (the participants; who is speaking to whom), the setting or context of social (where are the speaker speaking), the topic in discussion (what is being talked), and the function (why are the speaker speaking) are correlated and could become the important factors. The four components above are also related to social dimensions and could be the implicit analysis. They are the social distance, status scale, formality, and functional scale.

${ }^{1}$ IAIN Salatiga, Indonesia 
Furthermore, those social components influence the use of language in the multilingual region or community: which sociolinguistics is concerned with investigating the relationships between language and society with the goal being a better understanding of the structure of language and of how languages function in communication; the equivalent goal in the sociology of language is trying to discover how social structure can be better understood through the study of language, e.g., how certain linguistic features serve to characterize particular social arrangements (Wardaugh, 2006). Sociolinguistic uses for practical life very much, because the language as a tool of human verbal communication, of course, have certain rules on its usage. Sociolinguistics provides knowledge on how to use language in a certain aspect or social terms. Sociolinguistics will guide us in communicating with language, variety of language or style of what language should we use when we talk to a certain person. In addition, an Individual who studies such relationship is called as a sociolinguist. The scope of sociolinguistic is varied. Bilingualism and code-switching in society is part of a sociolinguistic study.

Education, occupation, and social class here dominantly discuss another factor of social attributes which can influence how society speak. In some dialect surveys, it has been found that, among those leaving the educational system at an early age, there is a bigger propensity to use forms which are approximately infrequent in the speech of those who go on to college. It seems to be the case that a person who spends a long time going through college or university will tend to have spoken language elements which determine from a lot of time spent working with the written language.

According to Stockwell (Nuranindya, 2011), a code is "a symbol of nationalism that is used by people to speak or communicate in a particular language, or dialect, or register, or accent, or style on different occasions and for different purposes." Similar to that, Ronald Wardaugh also maintains that code can be defined as "a system used for communication between two or more parties used on many occasions." Regarding both statements, the writer concludes, when two or more people communicate with each other in speech, we can call the system of communication that they employ a code. In code-switching case, people sometimes switch code within a domain or social situation. When there is some obvious change in the situation, such as the arrival of a new person, it is easy to explain the switch (Holmes, 2013, p. 35). The use of Code Switching reacted to the behaviors, class, ethnicity, and other social positions. Therefore, code-switching is not only reflecting the social situation but also uses as a means to create social situations.

Moreover, according to Dell as quoted by Fasold (Setiawatiningrum, 2013) there are eight factors to influence people switching a language: Situations, Participants, Ends, Act Sequences, Keys, Instrumentalities, Norms, Genres. Moreover, Several factors are usually the cause of the codeswitching are The speaker, Partner Speakers, The third speaker presence, The subject of conversation (topic), To generate a sense of humor, For prestige. To conclude, those six factors that cause over the switching code are essential in assessing the control of the code, because it focuses on the six factors that will shape the language used by the speaker and the situation faced by the speaker and hearer (Mustikawati, 2016). According to BPS (Central Bureau of Statistic), Salatiga has more than 192 thousand 
of people. In the region of Sidorejo itself, the people are counted about five thousand including female and male. This number also shows the variety of ethnicity and education background.

Additionally, Pulutan (Badan Pusat Statistik, 2018) as one of the little village in Sidorejo could get increasing number since the arrival of IAIN students after the built of new campus although not nameable as a registered resident. The students who are likely to prefer living in boarding house usually register by collecting the ID and Student Card to their owner of the boarding house. Because of such phenomena, the arrival of students as educated people and their use of language in casual chat or daily activity, their interaction with neighbors can give effect the way people communicate around in Pulutan.

In certain situations, there are people who speak for more than one language (Setiawati Darmojuwono, 2005). This phenomenon is called kedwibahasaan or bilingualism. According to Wardaugh, (Wardaugh, 2006, p. 100) A bilingual situation can produce still other effects on one or more of the languages involved. It can lead to loss, e.g., language loss among immigrants. But sometimes it leads to diffusion; that is, certain features spread from one language to the other (or others) as a result of the contact situation, particularly certain kinds of syntactic features.

In this proposal, the researcher uses sources from the ground and another from the book as a reference. The research about " Code Switching in Pulutan As The Reflection of Bilingualism" is non-extinct as far as the researcher did find. But the researches and journals about code-switching are many.

The undergraduate paper entitles "A Descriptive Analysis of Using CodeSwitching in English-Arabic Daily Conversation of Students Islamic Boarding School (Ta'mirul Islam, Surakarta, Central Java) by Amelia Fian Faulani has found the use of codeswitching where students in bilingual school tend to distract one language to another, in different sentences.

The undergraduate paper entitles "A Descriptive Analysis of English-Indonesian Code Switching Spoken by The English Teacher of MTs NU Salatiga in Academic Year of 2010/2011" by Inna Afni Fitriyah has found the use of code-switching in grammatical and sociolinguistic aspect in the teaching and learning process.

The journal entitles "Code Switching and Code Mixing in Indonesia: Study in Sociolinguistics" by Sumarsih has found the use of code-switching where word level is mostly found and reached the highest percentage among others (word, phrase, sentence class). The research was conducted by taking the data from City of Medan, Siantar, and Region of Mandailing Natal.

\section{Method}

This research will be conducted by using the qualitative descriptive method where the research is using a scientific background with a purpose to describe phenomena which occurs (Moleong, 2005, p. 5). The approach that is used is a case study as Creswell states, emphasizing the process and doing an intensive investigation of individual or community. As Yin states, a case study is not only to answer 'what' but also 'how' and 'why'. Qualitative descriptive provides a systematic, factual, and accurate description of a situation of area (Nuranindya, 2011). The research will be conducted in North Pulutan, one of the village in Sidorejo, Salatiga. 
The location was chosen according to the case study in the research which is also near to the location of Campus III IAIN and the existence of students' boarding house and little food shops are quite plentiful. The data sources are gained through observation (primary) and literature (secondary). The technique of collecting data is Simak Bebas Libat Cakap (Uninvolved Conversation Observation Technique) where the researcher only becomes the observer and don't participate in the conversation (Mahsun, 2013, p. 243). The data are collected from a students' boarding house and two little food shops in Pulutan which are representative. Representative here means researcher only take one sample for each in North Pulutan.

\section{Findings of The Study}

\subsection{Data and Research Result}

This chapter contains the research results of the collected data. The data have been taken from the recordings of casual talk in the selected area of North Pulutan. There are four objects of research who also have a position in society, predicated as the 'senior' people in Pulutan.

Table 1 The Participants of Code-Switching Research

\begin{tabular}{|c|c|c|c|c|c|c|}
\hline No. & Name & Age & $M / F^{\star}$ & Education & Occupation & LoR $^{\star \star}$ \\
\hline 1 & $\begin{array}{l}\text { S. Bambang } \\
\text { Suroso, } \\
\text { M.Soc., Sc. }\end{array}$ & 63 & $M$ & $\begin{array}{l}\text { Master } \\
\text { Degree Dev. } \\
\text { Finance } \\
\text { Birmingham, } \\
\text { UK }\end{array}$ & $\begin{array}{l}\text { Head of } \\
\text { Regional of } \\
\text { Director } \\
\text { General of } \\
\text { Budget of } \\
\text { Banten } \\
\text { Province, } \\
\text { Ministry of } \\
\text { Finance }\end{array}$ & $\begin{array}{l}\text { Swandaru } \\
\text { House }\end{array}$ \\
\hline 2 & Yulifiani & 41 & $F$ & $\begin{array}{l}\text { Vocational } \\
\text { High School }\end{array}$ & $\begin{array}{l}\text { BPR officer, } \\
\text { Advertising in } \\
\text { Suara } \\
\text { Merdeka, and } \\
\text { Merchant }\end{array}$ & $\begin{array}{l}\text { WM. } \\
\text { Bang } \\
\text { Zakky }\end{array}$ \\
\hline 3 & $\begin{array}{l}\text { Tri } \\
\text { Wahyuningsih }\end{array}$ & 48 & $\mathrm{~F}$ & $\begin{array}{l}\text { Senior High } \\
\text { School }\end{array}$ & $\begin{array}{l}\text { Homecare } \\
\text { Nurse, } \\
\text { Merchant }\end{array}$ & $\begin{array}{l}\text { Kedai } \\
\text { Mas Doel }\end{array}$ \\
\hline 4 & Imam & 41 & $M$ & $\begin{array}{l}\text { Senior High } \\
\text { School }\end{array}$ & $\begin{array}{l}\text { Gardener, } \\
\text { Project } \\
\text { Developer, } \\
\text { Merchant }\end{array}$ & $\begin{array}{l}\text { WM Bang } \\
\text { Zakky }\end{array}$ \\
\hline
\end{tabular}

*to distinguish gender type, $\mathrm{F}$ as Female $\mathrm{M}$ as Male

${ }^{*}$ LoR means Location of Research 
ISSN: (E) 2621-0835, (P) 2621-0843

Here is the result of code-switching according to the sentence the researchers have recorded :

Table 2 The result of Code Switching

\begin{tabular}{|c|c|c|}
\hline No & Words & Lexical Meaning \\
\hline 1 & Object & $\begin{array}{l}\text { "...mereka disini. Karena mereka } \\
\text { object kan itu" }\end{array}$ \\
\hline 2 & Plastik & "Plastiknya ojo sing kui ndhuk" \\
\hline 3 & Wedang & $\begin{array}{l}\text { "...nak wedang yo standar, enake } \\
\text { piye.." }\end{array}$ \\
\hline 4 & Soulmate & $\begin{array}{l}\text { "...bakwan dan tahu mercon kan } \\
\text { soulmate mbak." }\end{array}$ \\
\hline 5 & Solution & $\begin{array}{l}\text { "...Saya kira harusnya ada win- } \\
\text { win solution ya." }\end{array}$ \\
\hline 6 & Cashflow & $\begin{array}{l}\text { "...kalau kita tidak disiplin bayar } \\
\text { kas, nanti cashflow terganggu." }\end{array}$ \\
\hline 7 & Status quo & $\begin{array}{l}\text { "...menurut saya, orang-orang tua } \\
\text { itu status quo.". }\end{array}$ \\
\hline 8 & Double & $\begin{array}{l}\text { "Mi, geprek siji paket } \\
\text { double..paket } A . . "\end{array}$ \\
\hline 9 & Win-win & $\begin{array}{l}\text { "...Saya kira harusnya ada win- } \\
\text { win solution ya." }\end{array}$ \\
\hline 10 & Jarene & "jarene beda..." \\
\hline 11 & Persen & "..iki ya Allah tinggal telu persen" \\
\hline 12 & Sing & $\begin{array}{l}\text { "...sing meja samping itu kan } \\
\text { megah.." }\end{array}$ \\
\hline 13 & Mbukak & $\begin{array}{l}\text { “...tuh bapak kan mbukak kran, } \\
\text { tuh...” }\end{array}$ \\
\hline 14 & WA & "loh, kowe kok ya ora WA aku.." \\
\hline 15 & Chat & $\begin{array}{l}\text { "nak no, aku nge-chat e mas ... } \\
\text { ngono ya?" }\end{array}$ \\
\hline 16 & Tajemke & "Sini tak tajemke...bisa?...bisa?" \\
\hline 17 & Nyoh & "nyoh...tuh bapak kan.." \\
\hline 18 & Yes & $\begin{array}{l}\text { "...yes, } 5000 \text { (lima ribu rupiah) } \\
\text { lima ribu," }\end{array}$ \\
\hline 19 & Nggih & "nggih...hati-hati ya...". \\
\hline 20 & Nang & "ibuk nang warung ki lho ya..." \\
\hline 21 & Cah & "yang meja samping itu lho cah..." \\
\hline 22 & lyo & $\begin{array}{l}\text { "Iyo, es jeruk dua...proses, } \\
\text { proses.." }\end{array}$ \\
\hline 23 & Thank you & $\begin{array}{l}\text { "...yes, Okee, thank you aku } \\
\text { dikasih receh.." }\end{array}$ \\
\hline 24 & Bro & "halo mas...mas bro apa kabar?" \\
\hline
\end{tabular}

\subsection{Discussion}

In this study, the researcher will classify the analysis into three discussions and use an online dictionary (en.oxforddictionaries.com) to analyze the data. There are: The Forms of Code Switching, the lexical meanings, and thirdly is the language and what form that are used in the code switching. There are also the table and scanned 
file during the research was conducted. In this study, it is also necessary to reaffirm that not all data will be analyzed due to the limitation of the research.

The researcher relies on four participants whose locations are included in the research. All participants are also a citizen and called as 'senior' in the North Pulutan. Here is the identity descriptions based on the participants have confirmed, including Names, Ages, Sex, Education and Occupation Background, and Locations of Research. Moreover, the research result shows the sex (or gender) do not differ in code-switching words that uttered-even though gender or sex isn't underscored here-in this research., like what Rabbani and Mushtaq stated in their research :

The mean of code switching and code mixing scores of the sample was almost normally distributed which proposed that boys and girls do not differ in code switching and code mixing scores.

(Rida Rabbani, 2012)

\subsubsection{The Forms of Code Switching}

According to Oxford Dictionaries Online, (Press O. U., Word Classes or Part of Speech, 2018), All words belong to categories called word classes (or parts of speeches) according to the part they play in a sentence. The main word classes in English are Noun, Verb, Adjective, Adverb, Pronoun, Preposition, Conjunction, Determiner, Exclamation. In this research, the words only appear as six forms: Noun, Adjective, Pronoun, Verb, Determiner, and Exclamation. Here, the writer also wants to describe more the definitions above. The sources are taken from 1. Oxford English Dictionary (Press O. U., English Oxford Living Dictionaries, 2018) to resemble the view, and in order to give another definition, the writer also gives the definition from 2. Merriam Webster Dictionary (Incorporated, 2018).

In this research, not all forms of the word are analyzed. The researcher only analyzed the forms that exist.

1. Noun
a. Object
"...mereka disini. Karena mereka object kan itu"
b. Plastik
"Plastiknya ojo sing kui ndhuk"
c. Wedang
"...nak wedang yo standar, enake piye.."
d. Soulmate
"...bakwan dan tahu mercon kan soulmate mbak."
e. Solution

2. Adjective
a. Cashflow
"...kalau kita tidak disiplin bayar kas, nanti cashflow terganggu."
b. Status quo
"...menurut saya, orang-orang tua itu status quo."
c. Double
"Mi, geprek siji paket double..paket A.."
d. Win-win 


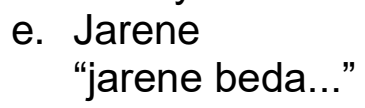

3. Adverb
a. Persen
“..iki ya Allah tinggal telu persen"

4. Pronoun
a. Sing
"...sing meja samping itu kan megah.."

5. Verb
a. Mbukak
"...tuh bapak kan mbukak kran, tuh..."
b. WA
"loh, kowe kok ya ora WA aku.."
c. Tajemke
"Sini tak tajemke...bisa?...bisa?"
d. Chat
"nak no, aku nge-chat e mas ... ngono ya?"

6. Determiner
a. Nyoh
"nyoh...tuh bapak kan.."

7. Exclamation
a. Yes
"...yes, 5000 (lima ribu rupiah) lima ribu,"
b. Nggih "nggih...hati-hati ya..."
c. Nang "ibuk nang warung ki lho ya..."
d. Cah "yang meja samping itu lho cah..."
e. Ndhuk "Plastiknya ojo sing kui ndhuk"
f. lyo "Iyo, es jeruk dua...proses, proses.."
g. Thank you "...yes, Okee, thank you aku dikasih receh.."
h. Bro "halo mas...mas bro apa kabar?"

\subsubsection{The Lexical Meanings of Code Switching}

According to Cambridge Dictionary (Press C. U., Cambridge Dictionary, 2018), lexical is relating to words. While according to Merriam Webster (Incorporated, 2018), the lexical meaning is the meaning of the base (such as the wordplay) in paradigm (such as play, plays, played). Here, the researcher uses the Oxford Dictionary and $\mathrm{KBBI}$ Daring to define the appropriate meaning. 
Table 3 The Words and its Lexical Meaning

\begin{tabular}{|c|c|c|c|}
\hline & Words & Type of Form & Lexical Meaning \\
\hline & Object & Noun & $\begin{array}{l}\text { A person or thing to which a } \\
\text { specified action or feeling is directed. }\end{array}$ \\
\hline & Plastik & Noun & $\begin{array}{l}\text { A synthetic material made from a } \\
\text { wide range of organic polymers such as } \\
\text { polyethylene, PVC, nylon, etc., that can } \\
\text { be molded into shape while soft, and } \\
\text { then set into a rigid or slightly elastic } \\
\text { form. }\end{array}$ \\
\hline & Wedang & Noun & $\begin{array}{l}\text { Drinks from sugar and coffee (tea, } \\
\text { ginger, etc.) which are usually brewed } \\
\text { with hot water, usually can warm the } \\
\text { body }\end{array}$ \\
\hline & Soulmate & Noun & $\begin{array}{l}\text { A person ideally suited to another } \\
\text { as a close friend or romantic partner. }\end{array}$ \\
\hline & Solution & Noun & $\begin{array}{l}\text { A means of solving a problem or } \\
\text { dealing with a difficult situation. }\end{array}$ \\
\hline & Cashflow & Adjective & $\begin{array}{l}\text { The study of language in relation } \\
\text { to social factors, including differences of } \\
\text { regional, class, and occupational } \\
\text { dialect, gender differences, and } \\
\text { bilingualism. }\end{array}$ \\
\hline quo & Status & Adjective & $\begin{array}{l}\text { The existing state of affairs, } \\
\text { especially regarding social or political } \\
\text { issues. }\end{array}$ \\
\hline & Double & Adjective & $\begin{array}{l}\text { Consisting of two equal, identical, } \\
\text { or similar parts or things. }\end{array}$ \\
\hline & Win-win & Adjective & $\begin{array}{l}\text { Of or denoting a situation in which } \\
\text { each party benefits in some way. }\end{array}$ \\
\hline & Jarene & Adjective & $\begin{array}{l}\text { Used in legal language or } \\
\text { humorously to refer to someone or } \\
\text { something already mentioned or named. }\end{array}$ \\
\hline & Persen & Adverb & $\begin{array}{l}\text { By a specified amount in or for } \\
\text { every hundred. }\end{array}$ \\
\hline & Sing & Pronoun & Which one \\
\hline & Mbukak & Verb & $\begin{array}{l}\text { Move (a door or window) so as to } \\
\text { leave a space allowing access and } \\
\text { vision. Unfold or be unfolded; spread } \\
\text { out. }\end{array}$ \\
\hline & WA & Verb & $\begin{array}{l}\text { WhatsApp; sending a message } \\
\text { through WA (instant messaging app) }\end{array}$ \\
\hline & Chat & Verb & $\begin{array}{l}\text { Exchange messages online in real } \\
\text { time with one or more simultaneous } \\
\text { users of a computer network. }\end{array}$ \\
\hline & Tajemke & Verb & $\begin{array}{l}\text { Sharpen; Make or become sharp } \\
\text { or sharper }\end{array}$ \\
\hline
\end{tabular}


ISSN: (E) 2621-0835, (P) 2621-0843

\begin{tabular}{|c|c|c|c|}
\hline & Nyoh & Determiner & Demonstrative; this \\
\hline & Yes & Exclamation & $\begin{array}{l}\text { Used to give an affirmative } \\
\text { response. }\end{array}$ \\
\hline & Nggih & Exclamation & $\begin{array}{l}\text { Okay : Used to give an affirmative } \\
\text { response. }\end{array}$ \\
\hline & Nang & Exclamation & $\begin{array}{l}\text { Sweetheart : Used as a term of } \\
\text { endearment or affectionate form of } \\
\text { address. }\end{array}$ \\
\hline & Cah & $\begin{array}{l}\text { Exclamation; } \\
\text { particle }\end{array}$ & $\begin{array}{l}\text { exclamation to express dislike, } \\
\text { insult, surprise, and so forth }\end{array}$ \\
\hline & lyo & Exclamation & $\begin{array}{l}\text { Right, true: Used to indicate } \\
\text { agreement or to acknowledge a } \\
\text { statement or order. }\end{array}$ \\
\hline you & Thank & Exclamation & $\begin{array}{l}\text { A polite expression used when } \\
\text { acknowledging a gift, service, or } \\
\text { compliment, or accepting or refusing an } \\
\text { offer. }\end{array}$ \\
\hline & Bro & Exclamation & $\begin{array}{l}\text { A male friend (often used as a } \\
\text { form of address) }\end{array}$ \\
\hline
\end{tabular}

\subsubsection{The language and forms that are used}

It comes to the result where English is dominated in the code-switching. Before that, the English word found is not derived from English, but it really English in a real context (see the example : not Objek, but Object. And the opposite: in Bahasa Indonesia, Plastik, not Plastic. Here's the chart result.

Figure 1 Chart of Dominant Language and Forms in Code Switching

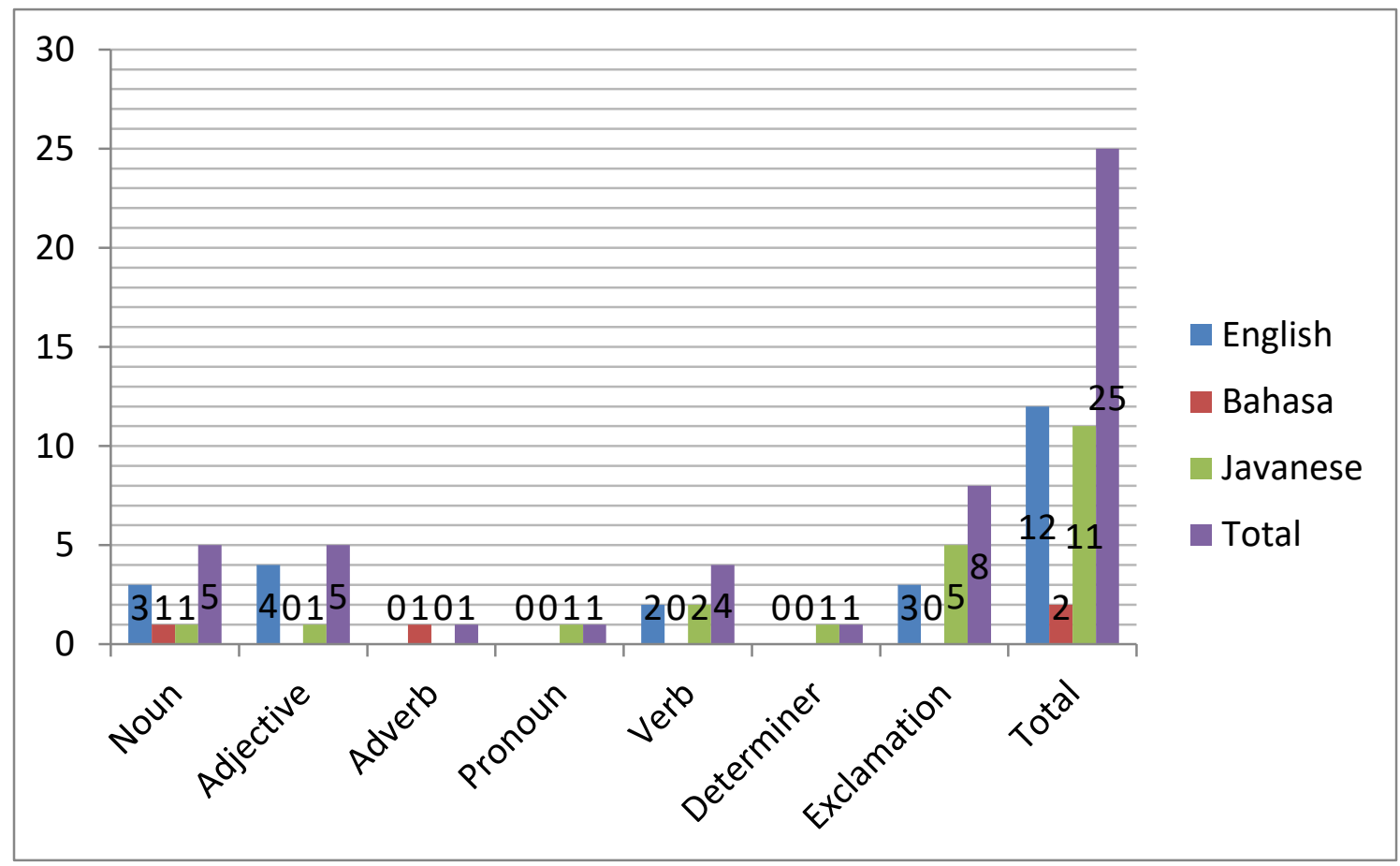


Based on the chart above, English is the most dominant language that is used in code-switching, secondly is Javanese, and the last is Bahasa Indonesia. Second, in the section of forms are dominated with Adjective and Noun. That will be explained in the next chart.

Figure 2 Chart of Word Forms in Code Switching

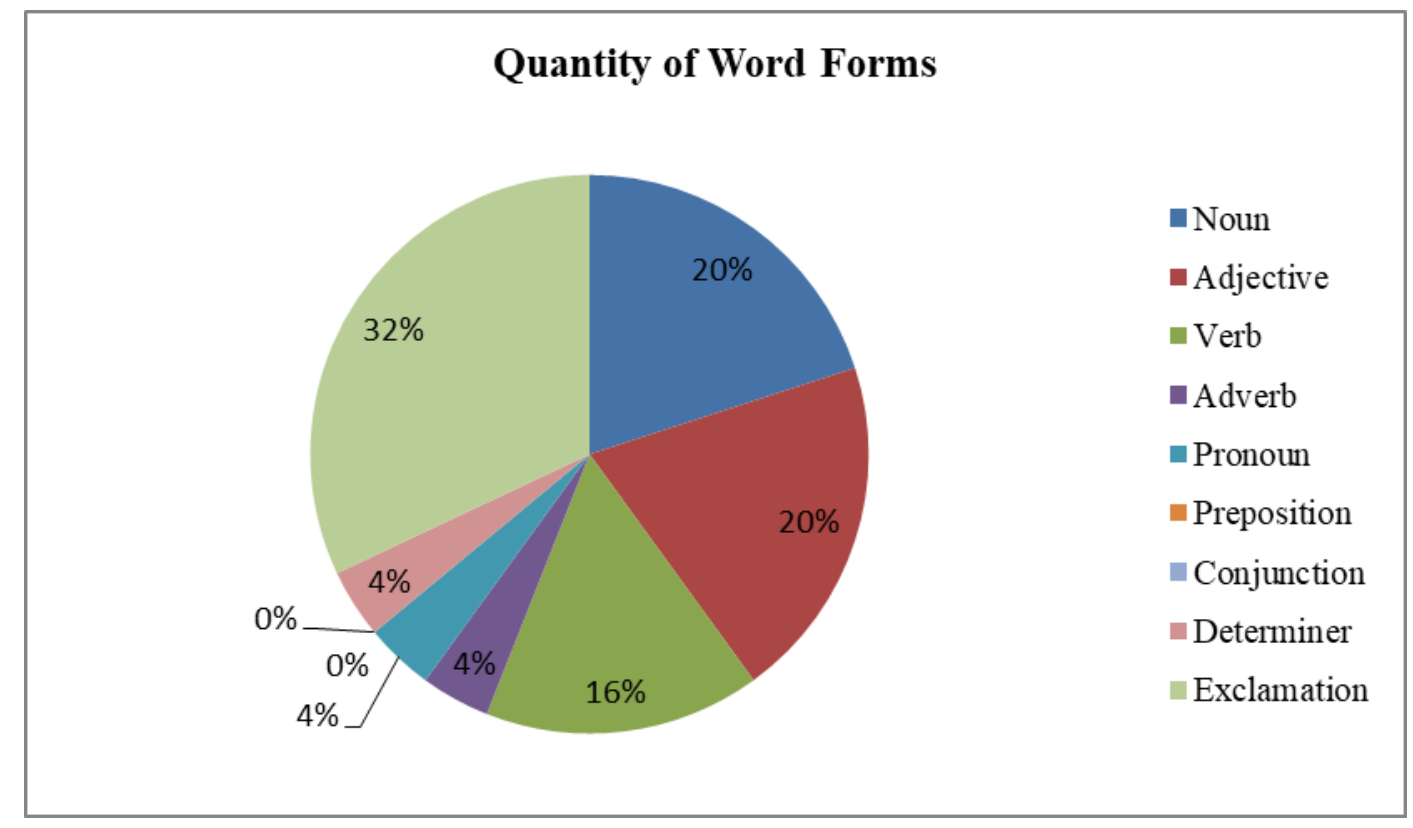

Table 4 shows the forms of words in the Code-Switching and its frequency

\begin{tabular}{cc}
\hline Forms of Code Switching (Words) & Frequency \\
\hline Noun & 5 \\
\hline Adjective & 5 \\
\hline Verb & 4 \\
\hline Adverb & 1 \\
\hline Pronoun & 1 \\
\hline Preposition & 0 \\
\hline Conjunction & 0 \\
\hline Determiner & 1 \\
\hline Exclamation & 8 \\
\hline Total & $\mathbf{2 5}$
\end{tabular}

Table 5 shows the frequency of language in the Code Switching

\section{Languages}

\begin{tabular}{ccc}
\hline English & Bahasa Indonesia & Javanese \\
\hline 12 & 2 & 11 \\
\hline
\end{tabular}

\section{Conclusion}

According to the result of research that has been conducted, English is dominantly used in the code-switching, the second is Javanese, and the last is Bahasa Indonesia, due to many newcomers who live in Pulutan shows, this can affect how society use language even in casual conversations. This code-switching 
reflected as bilingualism. The research only limits the location in the area of North Pulutan, where the university students preferably living near campus. But it is not possible if the research get to broaden and the area is not only in North Pulutan, so the result might be different. Another type of research: sociolinguistic, ethnolinguistic, and etcetera are suggested in order to develop social research and development.

\section{Acknowledgments}

However, this research will not be finished without support, advice, help, and encouragement from several people and institution. Hence, the writer would like to express special thanks to: IAIN Salatiga for the chance to conduct such research and for the grant (hibah) research, Ibu Sari Famularsih for the assistance and the counselor of the research, all of lecturers and staff from kampus asal, all of researchers' family and relatives, all of the participants in the research : Mr. Bambang Suroso M. Soc., Sc., Mrs. Yuli, Mr. Imam, Mrs. Tri for being kind giving their contributions in this research, The Go-jek drivers, all of the merchants who sell breakfast, lunch and dinner, and the photocopy officers for the minor but meaningful helps.

\section{References}

Badan Pusat Statistik. (2018, January 4). Retrieved from Badan Pusat Statistik Kota Salatiga: www.salatigakota.bps.go.id

Bloomfield, L. (1961). Language. New York: Holt Rinehart and Winston.

Holmes, J. (2013). An Introduction to Sosiolinguistic. New York: Routledge.

Mahsun. (2013). Metode Penelitian Bahasa. Jakarta: Raja Grafindo Persada.

Moleong, L. J. (2005). Metodologi Penelitian Kualitatif. Bandung: Remaja Rosdakarya.

Mustikawati, D. A. (2016). Code-Mixing and Code Switching in The Process of Learning. REGISTER Journal, 41-42.

Nuranindya, D. (2011). Analysis Of Code Switching And Code Mixing In The Teenlit Canting Cantiq. Semarang: Diponegoro University.

Press, C. U. (2018). Cambridge Dictionary. Retrieved October 18, 2018, from Cambridge Dictionary: https://dictionary.cambridge.org/dictionary/english/lexical

Press, C. U. (2018). Cambridge Dictionary. Retrieved October 26, 2018, from Cambridge Dictionary: https://dictionary.cambridge.org/dictionary/english/codeswitching

Press, O. U. (2018). English Oxford Living Dictionaries. Retrieved October 26, 2018, from Oxford Dictionaries: https://en.oxforddictionaries.com

Press, O. U. (2018). Word Classes or Part of Speech. Retrieved October 18, 2018, from English Oxford Living Dictionaries https://en.oxforddictionaries.com/grammar/word-classes-or-parts-of-speech

Rida Rabbani, M. H. (2012). Gender Difference in Code-Switching and Code-Mixing in Text Messages of Undergraduate Students . LANGUAGE IN INDIA, 346.

Samsuri. (1991). Analsis Bahasa. Jakarta: Penerbit Erlangga. 
Setiawati Darmojuwono, K. (2005). Aspek Kognitif Bahasa. In U. Y. Kushartanti, Pesona Bahasa (p. 27). Jakarta: Gramedia Pustaka Utama.

Setiawatiningrum, C. (2013). Code Switching in Daily Conversations Among UI Students of English Studies 2009 . Jakarta: FIB UI.

Wardaugh, R. (2006). An Introduction to Sociolinguistic. Victoria: Blackwell. 